\title{
Novel Inflammatory Biomarkers in Patients with Mycosis Fungoides Treated with Bexarotene
}

\author{
Funda Tamer and Ayla Gulekon \\ Department of Dermatology, Gazi University School of Medicine, Ankara, Turkey
}

\begin{abstract}
Mycosis fungoides (MF) is a skin lymphoma characterised by atypical T lymphocyte infiltration, which may present with patches and tumors in advanced stages. Treatment options in MF aim to reduce symptoms, since patients usually do not achieve complete cure. Bexarotene is used for treatment-resistant early stage MF and advanced stages of the disease. It has been suggested that white blood cell (WBC)/absolute lymphocyte count, WBC, absolute lymphocyte and eosinophil counts might be prognostic factors in MF. Therefore, we investigated the changes in complete blood count (CBC) parameters and CBC-derived inflammatory biomarkers in patients with MF treated with bexarotene. The results revealed that neutrophil (NE)\%, NE numbers, neutrophi//lymphocyte, derived neutrophil/lymphocyte, (neutrophil $\times$ monocytes)/lymphocyte and (neutrophils $\times$ monocytes $\times$ platelets)/lymphocyte counts decreased in all patients three months after bexarotene treatment. We suggest that these inflammatory biomarkers can be used in the follow-up of patients with MF receiving bexarotene treatment. Moreover, these results indicate that decrease in these inflammatory biomarkers may signify improvement of the disease.
\end{abstract}

Key Words: Bexarotene, Inflammatory biomarkers, Mycosis fungoides.

How to cite this article: Tamer F, Gulekon A. Novel Inflammatory Biomarkers in Patients with Mycosis Fungoides Treated with Bexarotene. J Coll Physicians Surg Pak 2021; 31(06):716-718.

\section{INTRODUCTION}

Mycosis fungoides (MF) is a skin lymphoma originating from epidermotropic clonal T-lymphocytes. It occurs in 5.6 cases per million; however, the incidence increases with age. ${ }^{1} \mathrm{MF}$ predominantly affects elderly patients over the age of 70 years. MF usually starts as eczema-like lesions, while advanced stages present with tumors or leukemic transformation. Treatment options aim to reduce symptoms and prevent disease progression. Nevertheless, patients usually do not achieve complete cure. ${ }^{1}$ Treating MF is based on the disease stage and efficacy of previous treatments. Bexarotene is a synthetic retinoid which is used to treat advanced disease. It is also effective in treatment-resistant cases of early stage MF. ${ }^{2}$ Bexarotene causes apoptosis of atypical T lymphocytes. However, the mechanism of action of bexarotene has not been fully understood. ${ }^{3}$

It has been suggested that complete blood count (CBC) parameters might provide prognostic clues in patients with MF. Increases in white blood cell (WBC), absolute lymphocyte and eosinophil counts have been associated with progressive disease. $^{4}$

Correspondence to: Dr. Funda Tamer, Department of Dermatology, Gazi University School of Medicine, Ankara, Turkey

E-mail: fundatmr@yahoo.com

Received: October 03, 2019; Revised: December 28, 2019;

Accepted: January 20, 2021

DOI: https://doi.org/10.29271/jcpsp.2021.06.716
In the light of this information, we investigated the effect of bexarotene treatment on $\mathrm{CBC}$ and $\mathrm{CBC}$-derived inflammatory biomarkers in patients with MF. The outcomes may suggest novel markers to be used in the follow-up of patients with MF to evaluate the improvement of the disease.

\section{CASE REPORT}

Hereby, we report five patients who received systemic bexarotene for the treatment of biopsy- proven MF. Patients' age, gender, disease duration, disease localisation, type of MF, lymph node involvement and stage of the disease were examined (Table I). The stage of the disease was defined based on TNMB classification. ${ }^{1}$ The patients received bexarotene capsules, $300 \mathrm{mg} / \mathrm{m}^{2} /$ day. The patients achieved partial response 12 weeks after bexarotene treatment. Inflammatory biomarkers that we analysed were neutrophil/lymphocyte count (N/L), monocyte/lymphocyte count (M/L), platelet/lymphocyte count (PLT/L), mean platelet volume/platelet count (MPV/PLT), derived neutrophil/lymphocyte count [neutrophils/(WBC-neutrophils)] (DNLR), (neutrophils $\times$ monocytes)/lymphocyte count $(\mathrm{N} \times \mathrm{M} / \mathrm{L})$ and (neutrophils $\times$ monocytes $\times$ platelets)/lymphocyte count $(\mathrm{N} \times \mathrm{M} \times \mathrm{P} / \mathrm{L}))^{5,6}$

The results revealed that lymphocyte percentage (\%) increased while neutrophil (NE)\% and neutrophil numbers (NE\#) decreased in all patients after bexarotene treatment. The rest of $C B C$ parameters did not change significantly. Nevertheless, WBC count decreased in four patients and stayed same in one patient. Leukopenia was observed in only one patient after bexarotene treatment. 
Table I: Demographics and disease characteristics of the patients.

\begin{tabular}{|c|c|c|c|c|c|c|}
\hline Age/ Gender & $\begin{array}{c}\text { Disease } \\
\text { duration } \\
\text { (years) }\end{array}$ & Localisation & MF variants & $\begin{array}{l}\text { Sezary } \\
\text { cells }\end{array}$ & Lymph nodes & MF stage \\
\hline $43 / M$ & 6 & face, trunk, extremities & large-cell transformation & $\mathrm{N}$ & $\begin{array}{c}\text { left } \\
\text { axillary }\end{array}$ & IVA $(\mathrm{T} 2, \mathrm{~N} 3, \mathrm{M} 0, \mathrm{~B} 0)$ \\
\hline $55 / F$ & 15 & trunk, extremities & classic & $\mathrm{N}$ & $\begin{array}{l}\text { bilateral } \\
\text { inguinal }\end{array}$ & IIA $(\mathrm{T} 2, \mathrm{~N} 1, \mathrm{M} 0, \mathrm{~B} 0)$ \\
\hline $49 / M$ & 25 & trunk & poikilodermatous & $\mathrm{N}$ & $\begin{array}{l}\text { bilateral } \\
\text { cervical }\end{array}$ & IIA $(\mathrm{T} 2, \mathrm{~N} 1, \mathrm{M} 0, \mathrm{~B} 0)$ \\
\hline $70 / \mathrm{M}$ & 6 & face, trunk, extremities & folliculotrophic & $<5 \%$ & - & IIB $(\mathrm{T} 3, \mathrm{~N} 0, \mathrm{M} 0, \mathrm{BO})$ \\
\hline $62 / M$ & 3 & erythrodermic & erythrodermic & N & $\begin{array}{l}\text { bilateral } \\
\text { inguinal }\end{array}$ & IVA $(\mathrm{T} 4, \mathrm{~N} 1, \mathrm{M} 0, \mathrm{~B} 0)$ \\
\hline
\end{tabular}

Table II: Hemogram parameters of the patients before and three months after bexarotene treatment.

\begin{tabular}{|c|c|c|c|c|c|c|c|c|c|c|}
\hline & \multicolumn{2}{|l|}{ Patient 1} & \multicolumn{2}{|l|}{ Patient 2} & \multicolumn{2}{|l|}{ Patient 3} & \multicolumn{2}{|l|}{ Patient 4} & \multicolumn{2}{|l|}{ Patient 5} \\
\hline & $\begin{array}{l}\text { Before } \\
\text { treatment }\end{array}$ & $\begin{array}{l}\text { After } \\
\text { treatment }\end{array}$ & $\begin{array}{l}\text { Before } \\
\text { treatment }\end{array}$ & $\begin{array}{l}\text { After } \\
\text { treatment }\end{array}$ & $\begin{array}{l}\text { Before } \\
\text { treatment }\end{array}$ & $\begin{array}{l}\text { After } \\
\text { treatment }\end{array}$ & $\begin{array}{l}\text { Before } \\
\text { treatment }\end{array}$ & $\begin{array}{l}\text { After } \\
\text { treatment }\end{array}$ & $\begin{array}{l}\text { Before } \\
\text { treatment }\end{array}$ & $\begin{array}{l}\text { After } \\
\text { treatment }\end{array}$ \\
\hline WBC $\left(\times 10^{3} / \mu \mathrm{L}\right)$ & 5.6 & 3.5 & 8.3 & 6.5 & 9.8 & 6.2 & 6.7 & 6.7 & 12.4 & 8 \\
\hline $\mathrm{PLT}\left(\times 10^{3} / \mu \mathrm{L}\right)$ & 249 & 351 & 222.6 & 322 & 236 & 245 & 273 & 254 & 304 & 154 \\
\hline MPV (fL) & 8.8 & 7.9 & 8.6 & 8.2 & 10.1 & 10.3 & 10.5 & 10.9 & 9 & 11.5 \\
\hline LY\% & 21.3 & 25.7 & 25.1 & 40 & 33.6 & 38 & 20.9 & 32.4 & 16.1 & 21 \\
\hline MO\% & 7.6 & 9.2 & 6.6 & 7.9 & 6.8 & 10.8 & 7.8 & 6.8 & 6.1 & 3.5 \\
\hline NE\% & 68.7 & 60.2 & 66.6 & 49 & 52.9 & 46.3 & 70.1 & 58.6 & 76.5 & 74.2 \\
\hline EO\% & 1.7 & 2.4 & 1.2 & 2.2 & 5.6 & 3.8 & 0.9 & 1.6 & 1.1 & 0.9 \\
\hline BA\% & 0.7 & 2.3 & 0.3 & 0.6 & 1.1 & 1.1 & 0.3 & 0.6 & 0.2 & 0.4 \\
\hline LY\# $\left(x 10^{3} / \mu \mathrm{L}\right)$ & 1.2 & 0.9 & 2.1 & 2.6 & 3.3 & 2.3 & 1.4 & 2.1 & 2 & 1.7 \\
\hline $\mathrm{MO \#}\left(\times 10^{3} / \mu \mathrm{L}\right)$ & 0.4 & 0.3 & 0.5 & 0.5 & 0.6 & 0.6 & 0.5 & 0.4 & 0.7 & 0.2 \\
\hline $\mathrm{NE} \#\left(\times 10^{3} / \mu \mathrm{L}\right)$ & 3.9 & 2.1 & 5.5 & 3.2 & 5.2 & 2.9 & 4.7 & 3.9 & 9.4 & 6 \\
\hline EO\# $\left(\times 10^{3} / \mu \mathrm{L}\right)$ & 0.1 & 0.08 & 0.1 & 0.1 & 0.5 & 0.2 & 0.06 & 0.1 & 0.1 & 0.07 \\
\hline BA\# $\left(x 10^{3} / \mu \mathrm{L}\right)$ & 0.06 & 0.08 & 0.03 & 0.04 & 0.1 & 0.07 & 0.02 & 0.04 & 0.03 & 0.03 \\
\hline
\end{tabular}

Table III: Inflammatory biomarkers before and three months after bexarotene treatment.

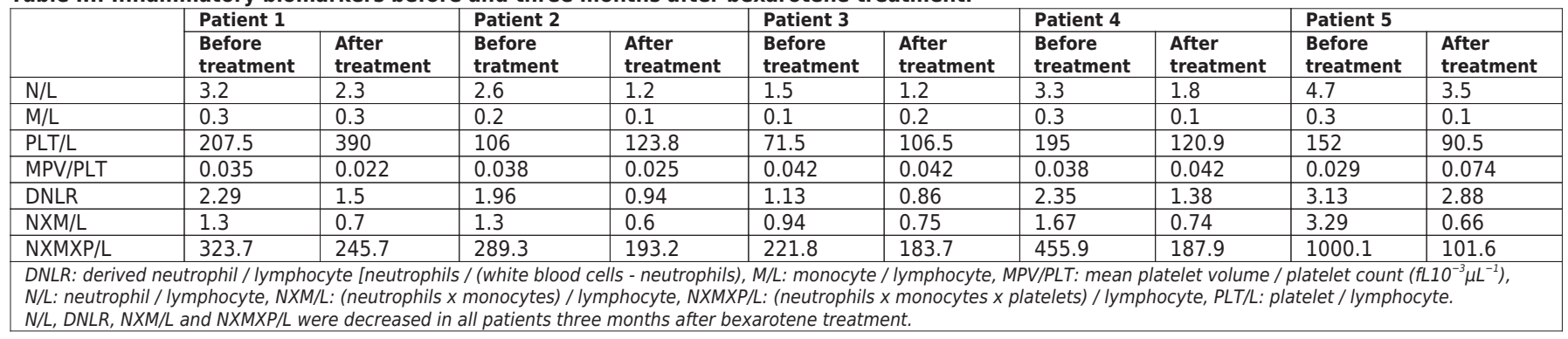

Within this study, N/L, DNLR, N $\times M / L$ and $N \times M \times P / L$ decreased in all patients three months after bexarotene treatment. However, M/L decreased in three patients, increased in one and stayed same in one patient. PLT/L increased in three and decreased in two patients. MPV/PLT increased in two patients, decreased in two and stayed same in one patient. CBC parameters and CBC-derived inflammatory biomarkers of the patients before and three months after bexarotene treatment are shown in Tables II and III.

\section{DISCUSSION}

Bexarotene is a safe and successful choice for the management of cutaneous T-cell lymphoma (CTCL). Bexarotene facilitates atypical T lymphocyte apoptosis sparing the cutaneous T-regulatory cells. Hypertriglyceridemia and hypothyroidism are well documented side effects of systemic bexarotene treatment. ${ }^{7}$
Furthermore, Abbott et al. reported leukopenia and neutropenia after bexarotene treatment for CTCL. ${ }^{8}$ Duvic et al. reported leukopenia in $11 \%$ of the patients who received bexarotene. Leukopenia was observed as a result of decreased polymorphonuclear leukocyte count. ${ }^{9}$ Within this study, WBC count decreased in four patients; however, WBC counts were within normal limits in these patients except for one. As a result, leukpenia was observed only in one patient. Furthermore, hypertriglyceridemia and hypothyroidism were observed in all patients after bexarotene treatment. However, these side effects did not lead to cessation of the bexarotene treatment.

Disease severity, systemic involvement, efficacy of treatment, histological transformation and high serum lactate dehydrogenase (LDH) levels can be used to determine the prognosis of CTCL. Tancrède-Bohin et al. reported that raised absolute eosinophil count might be associated with disease progression 
in CTCL. Furthermore, elevated WBC, absolute lymphocyte and eosinophil counts and WBC/absolute lymphocyte count have been associated with increased risk for progression and mortality in MF. ${ }^{4,10,11}$ Ozbagcivan investigated the prognostic value of mean platelet volume (MPV) in early stage MF; however, no correlation was detected between MPV and disease progression during the 5-year follow-up of patients. ${ }^{12}$ Response to bexarotene treatment is usually obtained within two months. ${ }^{9}$ Therefore, we evaluated the alteration in CBC parameters and CBC-derived inflammatory biomarkers in MF patients after three months of treatment with bexarotene. Among the prognostic factors which were reported previously, we detected decreased WBC counts in four patients. However, all patients showed decreased $\mathrm{NE} \%$ and $\mathrm{NE}$ \# after bexarotene treatment. As peripheral blood neutrophil activation has been implicated in MF pathophysiology, bexarotene may have an effect through neutrophils in the treatment of the disease. ${ }^{13}$

CBC-derived inflammatory biomarkers have been investigated in various solid tumors and hematological malignancies including multiple myeloma, non-Hodgkin lymphoma and diffuse large B-cell lymphoma. However, prognostic role of CBCderived inflammatory biomarkers in MF still remains controversial. ${ }^{12,14}$ It has been proposed that high N/L and PLT/L levels were related to proggressive disease. ${ }^{12}$ On the other hand, Eren et al. reported no correlation between $\mathrm{N} / \mathrm{L}$ and disease progression, time to progression or treatment demand. However, a few studies have been reported in the medical literature investigating inflammatory biomarkers in $M F{ }^{14}$ Our results revealed that bexarotene led to decrease in N/L, DNLR, N×M/L and $\mathrm{N} \times \mathrm{M} \times \mathrm{P} / \mathrm{L}$ in patients with MF. Decrease in these inflammatory biomarkers may signify improvement of the disease. Therefore, we suggest that decrease in $N / L, D N L R, N \times M / L$ and $N \times M \times P / L$ may be helpful in the follow-up of patients who are diagnosed with MF and treated with bexarotene. Furthermore, N/L, DNLR, $\mathrm{N} \times \mathrm{M} / \mathrm{L}$ and $\mathrm{N} \times \mathrm{M} \times \mathrm{P} / \mathrm{L}$ may be regarded as prognostic factors in MF. However, larger clinical studies are required for the confirmation of these results.

\section{PATIENTS' CONSENT:}

Informed consents were obtained from the patients.

\section{CONFLICT OF INTEREST:}

The authors declared no conflict of interest.

\section{AUTHORS' CONTRIBUTION:}

FT: Design of the manuscript, analysis of data for the manuscript, literature search, drafting and revising the intellectual content of the manuscript, final approval, agreement to be accountable for all aspects of the manuscript.

AG: Design of the manuscript, drafting and revising the intellectual content of the manuscript, final approval, agreement to be accountable for all aspects of the manuscript.

\section{REFERENCES}

1. Larocca C, Kupper T. Mycosis fungoides and Sézary syndrome: An update. Hematol Oncol Clin North Am 2019; 33(1):103-20. Doi: 10.1016/j.hoc.2018.09.001.

2. Panchal MR, Scarisbrick J]. The utility of bexarotene in mycosis fungoides and Sézary syndrome. Onco Targets Ther 2015; 8:367-73. Doi: 10.2147/OTT.S61308.

3. Schadt CR. Topical and oral bexarotene. Dermatol Ther 2013; 26(5):400-3. Doi: 10.1111/dth.12087.

4. Dulmage B, Geskin L, Guitart J, Akilov OE. The biomarker landscape in mycosis fungoides and Sézary syndrome. Exp Dermatol 2017; 26(8):668-76. Doi: 10.1111/exd.13261.

5. Djordjevic D, Rondovic G, Surbatovic M, Stanojevic I, Udovicic I, Andjelic T, et al. Neutrophil-to-lymphocyte ratio, monocyte-to-lymphocyte ratio, platelet-to-lymphocyte ratio, and mean platelet volume-to-platelet count ratio as biomarkers in critically ill and injured patients: Which ratio to choose to predict outcome and nature of bacteremia? Mediators Inflamm 2018; 2018:3758068. Doi: 10.1155/2018/3758068.

6. Pinna A, Porcu T, D'Amico-Ricci G, Dore S, Boscia F, Paliogiannis $P$, et al. Complete blood cell count-derived inflammation biomarkers in men with age-related macular degeneration. Ocul Immunol Inflamm 2019; 27(6):932-6. Doi: 10. 1080/ 09273948.2018.1485960.

7. Väkevä L, Ranki A, Hahtola S. Ten-year experience of bexarotene therapy for cutaneous T-cell lymphoma in Finland. Acta Derm Venereol 2012; 92(3):258-63. Doi: 10.2340/0001 5555-1359.

8. Abbott RA, Whittaker SJ, Morris SL, Russell-Jones R, Hung T, Bashir SJ, et al. Bexarotene therapy for mycosis fungoides and Sézary syndrome. BrJ Dermatol 2009; 160(6): 1299-307. Doi: 10.1111/j.1365-2133.2009.09037.x.

9. Duvic M, Hymes K, Heald P, Breneman D, Martin AG, Myskowski $P$, et al. Bexarotene is effective and safe for treatment of refractory advanced-stage cutaneous T-cell lymphoma: Multinational phase II-III trial results. J Clin Oncol 2001; 19(9):2456-71. Doi: 10.1200/JCO.2001.19.9.2456.

10. Tancrède-Bohin $E$, lonescu $M A$, de La Salmonière $P$, Dupuy $A$, Rivet J, Rybojad M, et al. Prognostic value of blood eosinophilia in primary cutaneous T-cell lymphomas. Arch Dermatol 2004; 140(9):1057-61. Doi: 10.1001/archderm.140.9.1057.

11. Scarisbrick JJ, Prince HM, Vermeer MH, Quaglino P, Horwitz S, Porcu $P$, et al. Cutaneous lymphoma international consortium study of outcome in advanced stages of mycosis fungoides and Sézary syndrome: Effect of specific prognostic markers on survival and development of a prognostic model. J Clin Oncol 2015; 33(32):3766-73. Doi: 10.1200/JCO.2015.61.7142.

12. Ozbagcivan 0 . Prognostic significance of neutrophil/lymphocyte ratio, platelet/lymphocyte ratio and mean platelet volume in the early stage mycosis fungoides. Dokuz Eylul Universitesi Tip Fakultesi Dergisi 2019; 33(2):149-57. Doi: 10.5505/deutfd. 2019.55706.

13. Goddard DS, Yamanaka K, Kupper TS, Jones DA. Activation of neutrophils in cutaneous T-cell lymphoma. Clin Cancer Res 2005; 11(23):8243-9. Doi: 10.1158/1078-0432.CCR-05-1434.

14. Eren R, Nizam N, Doğu MH, Mercan S, Erdemir AV, Suyanı E. Evaluation of neutrophil-lymphocyte ratio in patients with early-stage mycosis fungoides. Ann Hematol 2016; 95(11):1853-7. Doi: 10.1007/s00277-016-2779-7. 